\title{
The relative importance of religion and education on university students' views of evolution in the Deep South and state science standards across the United States
}

\author{
Leslie J Rissler, Sarah I Duncan and Nicholas M Caruso
}

\begin{abstract}
Background: There is a negative relationship between education and religiosity and a positive relationship between education and acceptance of evolution, but how this manifests in college students who differ in degree of religiosity and prior educational experiences is unclear. We focused our study on the relative importance of education and religion on evolution understanding for college students at a large, public university in the Deep South

Methods: We used a structural equation model incorporating both acceptance and knowledge of evolution to evaluate the relative influence of religion and education on evolution understanding of 2,999 surveyed students. We further focused on acceptance of evolution and academic level, college major, high school experience, religion, and religiosity. We conducted pre and post course evaluations in three biology classes, and finally we tested the relationships between the quality of K-12 state science standards and states' religiosity and educational attainment.

Results: We found that the degree of religiosity mattered significantly more than education when predicting students' understanding of evolution. When we focused on acceptance of evolution only, students taught evolution or neither evolution nor creationism in high school had significantly higher acceptance than those taught both evolution and creationism or just creationism. Science majors always outscored non-science majors, and not religious students significantly outperformed religious students. Highly religious students were more likely to reject evolution even though they understood that the scientific community accepted the theory of evolution. Overall, students in two of three biology classes increased their acceptance of evolution, but only those students that seldom/never attended religious services improved. K-12 state science standard grades were significantly and negatively correlated with measures of state religiosity and significantly and positively correlated with measures of state educational attainment.

Conclusions: Religiosity, rather than education, best explains views on evolution. In areas of the country where the vast majority of residents believe in God and the literal truth of the Bible, students may be hampered as they enter and progress through college. These same states tend to have lower state science standards and lower levels of educational attainment.
\end{abstract}

Keywords: Alabama; Majors; Science; University; MATE; Acceptance; KEE

\footnotetext{
* Correspondence: rissler@ua.edu

Department of Biological Sciences, University of Alabama, MHB Hall, Box
} 870345, Tuscaloosa, AL 35487, USA 


\section{Background}

There is much opposition to evolution in the public sphere, especially in America. The oft-cited article by Miller et al. (2006) summarized 33 European countries and Japan on people's understanding of evolution, and America ranked lower than every country but one. This poor performance is not reflective of America's general scientific literacy; the United States is about average in science literacy, though below average in mathematics, according to the Programme for International Student Assessment (PISA), which tests 15-year old students across 65 countries in math, science, and other disciplines (Organisation for Economic Co-operation and Development OECD 2014). Why, then, is the subject of evolution so misunderstood, especially when compared to other theories like the germ theory of disease, atomic theory, or cell theory (e.g., Rutledge and Sadler 2011)? The strong and negative correlation $(r=-0.608, P=0.0001)$ between belief in God and acceptance of evolution across the same areas in Miller et al. (2006) suggests that religiosity drives some of the resistance to evolution (Coyne 2012). Studies show that religiosity is associated with low scientific literacy in general (e.g., Heddy and Nadelson 2012); in fact, religiosity in the United States is more predictive of scientific literacy than gender, race, or income (Sherkat 2011). A recent Gallup Poll (2014a) found that almost equal percentages of Americans believed in a young-earth creationist view of human origins (i.e., humans were created in their present form within last 10,000 years) $(42 \%)$ vs. one where humans evolved from earlier organisms over millions of years (50\%). But of the latter, approximately a third think that evolution happened without a god, while two-thirds believe God must have started the process. These patterns have remained relatively stable for 30 years (Gallup Poll 2014a). Thus, the consistent and continued rejection of evolution may be a consequence of the extreme religiosity of Americans (Coyne 2012), though Heddy and Nadelson (2013) show that across all 50 states, the degree of religiosity $(r=-0.76$; $\mathrm{P}<0.05)$ and two measures of education [numbers of bachelor degrees $(r=0.76 ; \mathrm{P}<0.05)$ and advanced degrees $(\mathrm{r}=0.78 ; \mathrm{P}<0.05)$ awarded] are about equally correlated with acceptance of evolution.

There is a positive correlation between science literacy and acceptance of evolution at the country (Heddy and Nadelson 2012), state (Heddy and Nadelson 2013), and individual levels (Nadelson and Sinatra 2009; Sustersic 2007). As scientific education increases, religiosity decreases (Ecklund 2010; Heddy and Nadelson 2012; Larson and Witham 1997, 1998). Roughly 20\% of high school students, $52 \%$ of college graduates, and $65 \%$ of postgraduates accept evolution (Brumfiel 2005). Studies on the impact of high school education, in particular, on acceptance of evolution are few, but those that do exist show that early exposure to evolution increases scientific literacy in biology (Moore et al. 2009, 2011). High school biology classes are the single most important arenas for exposure to evolution, and teachers are the most important school-based factor in student learning (Goldhaber and Anthony 2003; National Research Council 2001). For many Americans, high school graduation marks the end of formal education, and for others it is the foundation for higher education at the college and graduate levels.

Unfortunately K-12 science standards vary widely across the United States (Braden et al. 2000; Gross 2005; Lerner 2000; Swanson 2005), and according to a 2009 survey by the National Center for Science Education (NCSE), only $76 \%$ of states (including the District of Columbia) received a passing grade (a C or greater) (Mead and Mates 2009). Five states (Alabama, Louisiana, Oklahoma, Texas, and West Virginia) received a failing grade for the quality of their science standards because either the treatment of evolution was absent or made defunct due to inclusion of creationist jargon and/or disclaimers. In fact, Alabama (the worst state) received an F- because there is an evolution disclaimer in the preface of the standards, no treatment of human evolution, and only limited mention of the "e-word" (Mead and Mates 2009). Alabama is the only state with an evolution disclaimer (Additional file 1), and since 1996 the Alabama State Board of Education has required that this disclaimer be placed in all high school biology textbooks (http://alex.state.al.us/staticfiles/2005_ AL_Science_Course_of_Study.pdf).

Even if high quality science standards are in place, a large percentage (at least a third) of biology teachers (K-12) (see Moore 2002; Moore et al. 2009) in the United States are creationists (summarized in Moore and Cotner 2009). Therefore, students may be exposed to personal religious beliefs or outright hostility toward evolution rather than scientific evidence, regardless of the standards (Aguillard 1999; Bandoli 2008; Berkman et al. 2008; Griffith and Brem 2004; Moore 2008; Skoog and Bilica 2002; Rutledge and Warden 2000; Trani 2004). There can also be community pressures placed on the teachers that do try to teach evolution, which can lead them to deemphasize or eliminate the topic altogether (Berkman et al. 2008; Griffith and Brem 2004). In the only nationwide survey of high school science teachers $(n=939)$, Berkman et al. (2008) found that at least $17 \%$ of biology teachers are young-earth creationists, and about one in eight teach creationism or intelligent design in a positive light. Only $23 \%$ of teachers strongly agreed that evolution is the unifying theme of biology, as accepted by the National Academy of Science and the National Research Council. Teachers that had the largest number of college-level courses in biology and life science devoted significantly more time $(60 \%)$ to evolution than teachers that were less prepared 
(Berkman et al. 2008). Therefore, both personal beliefs and the level of scientific literacy of teachers were important when explaining the variance in the number of hours devoted to evolution in high school biology classes (Berkman et al. 2008; Paz-y-Mino and Espinosa 2009; Trani 2004).

What does all this mean for the scientific literacy of students that enter college? In the few studies that have been conducted, college students with religious worldviews find it difficult to accept evolutionary concepts (e.g., Chinsamy and Plagányi 2008; Miller et al. 2006; Moore et al. 2009; Sinclair et al. 1997). According to Astin et al. (2005) 26\% of freshman at colleges and universities across America are born-again Christians. Several studies (e.g., Alters and Nelson 2002; Sinclair et al. 1997) show that "...adults' views on evolution are remarkably impervious to instruction” (Chinsamy and Plagányi 2008), and many demonstrate that religious beliefs often lead to a misunderstanding of evolution (Meadows et al. 2000; Winslow et al. 2011). Moore and Cotner (2009) reported that students with high school courses that included evolution (but not creationism) were significantly more likely to accept evolution than students with classes that included creationism (with or without evolution). Not only acceptance, but also knowledge of evolution, is higher for those students who had been taught evolution (but not creationism) in high school (Moore et al. 2009). Thus in the few studies that have been done (Moore et al. 2009; Wagler and Wagler 2013), college students' acceptance and knowledge of evolution are correlated with religious views and course work in high school biology classes.

The data are ambiguous in regard to whether evolution education in college improves students' acceptance of evolution, and whether this varies across majors (but see Paz-y-Mino and Espinosa 2009). For example, Wilson (2005) and Ingram and Nelson (2006) indicated that college instruction does increase acceptance, though changes were small and happened only for those students that were initially undecided, at least in the Ingram and Nelson (2006) study (reviewed in Wiles and Alters 2011). Two studies (Bishop and Anderson 1990; Lawson and Worsnop 1992) found no evidence of improvement. In fact there is only one study that we are aware of showing a strong improvement in student acceptance of evolution post instruction (Wiles and Alters 2011), quantified by the Measure of the Acceptance of the Theory of Evolution (MATE; Rutledge and Sadler 2007; Rutledge and Warden 1999). However, this study was on gifted high school students, not college students. Wiles and Alters' (2011) study used intensive instruction to address specific hypothesized impediments to acceptance (e.g., false dichotomy between science and religion; relationship between evolution and race; methods in dating; origin of life; etc.), although in the end, the authors were unable to determine which educational experiences most influenced acceptance of evolution.

While there is an overall negative relationship between education and religiosity and an overall positive relationship between education and acceptance of evolution, how this manifests in college students who differ in both degree of religiosity and prior educational experiences is not well understood. In addition, most of the studies that examine students' acceptance of evolution are regionally biased, with several in the Midwest (particularly Minnesota) and a few in the northeastern United States (Wagler and Wagler 2013). Because factors that influence the acceptance of evolution vary regionally across the United States (e.g., the degree of religiosity and educational attainment, see Heddy and Nadelson 2013), we focused our study on a relatively understudied area the Deep South. We examine the relative importance of religion and education (high school and college instruction) on evolution understanding of college students at a large, public university. We investigated whether acceptance of evolution improves with greater tenure at university, and if science majors have higher acceptance than non-science majors. We also investigated whether religiosity was associated with lower acceptance, irrespective of education. Using pre and post course evaluations, we investigated whether students improved their acceptance of evolution in three biology classes, and if students' degree of religiosity mattered. We place our work in a broader context by examining the relationships between state religiosity and state educational attainment to the quality of $\mathrm{K}-12$ state science standards, as measured by the National Center for Science Education (Mead and Mates 2009). We predicted that states having higher quality standards would also have lower degrees of religiosity and higher measures of educational attainment.

\section{Methods}

University-Wide Survey

Our survey was distributed in three ways. First, The University of Alabama Office of Institutional Effectiveness, sent an email with a link to the online survey (Additional file 2) to a random sample of 2,000 students in each academic class (freshman, sophomore, junior, senior) enrolled in spring semester 2010. Each potential respondent was reminded of the survey two times if they had not responded. Similarly, the following academic year, in fall 2010, another random sample of 8,000 students was emailed and asked to take the survey. Students were asked to respond to the survey only once. Of those 16,000 surveys sent campus-wide, 2,654 were completed. Second, we sent an email to 51 instructors, spanning a broad range of fields, at the same university to ask if we could administer the survey during their classes. Thirteen responded, and we obtained 760 surveys by this method. Third, the survey 
was administered in person to three courses in the Department of Biological Sciences for pre and post course assessments. We added only the post course surveys $(\mathrm{n}=154)$ to the data collected by the first two methods for the university-wide data set since all surveys were anonymous and we did not want to include duplicate responses. All surveys were administered between 2010-2011. If more than $10 \%$ of the questions in any survey were not answered, that survey was not included in the final data set. Additionally, if all questions on a survey had the same answer (e.g., all C's) or other similar duplicitous responses, they were removed from the final data set. The total number of surveys used in the final university-wide data set was 2,999 - a response rate of $16.67 \%$.

We used the MATE (Rutledge and Sadler 2007; Rutledge and Warden 1999) to assess acceptance of evolution. The MATE is a 20-item Likert-scale instrument that has six subscales focused on 1) the process of evolution, 2) scientific validity of the theory, 3) human evolution, 4) evidence, 5) scientific community's view of evolution, and 6) the age of the Earth (Additional file 2, questions \#1 - \#20). The MATE has been found to be internally consistent, stable over time, and robust in its ability to reliably assess the acceptance of evolutionary theory in different populations (e.g., Rutledge and Sadler 2007; Rutledge and Warden 1999); however, a recent review (Wagler and Wagler 2013) suggested that all new studies test for construct validity. Therefore, we examine validity and internal consistency of the MATE for our population following the methodology of Rutledge and Warden (1999) and Rutledge and Sadler (2007).

Because the MATE is said to assess only "acceptance" of evolution (reviewed in Wagler and Wagler 2013), we added two questions from the Knowledge of Evolution Exam (KEE; Cotner et al. 2010; Moore et al. 2009; Schauer et al. 2014) to better assess students' "knowledge" of evolution (Additional file 2, questions \#33 and \#34). MATE scores were assigned based on scoring instructions defined in Appendix B of Rutledge and Sadler (2007). Categories of evolution acceptance are based on Rutledge and Warden (1999): Very High Acceptance: 89-100, High Acceptance: 77-88 Moderate Acceptance: 65-76, Low Acceptance: 53-64, Very Low Acceptance: 20-52. The two KEE questions were scored as follows: a value of 0 was given for two incorrect answers; a value of 1 was given for one correct answer, and a value of 2 for two correct answers.

Three additional questions were public polling questions about the origin and development of humans taken from Gallup polls in 1982-2014 (Additional file 2, questions \#21 and \#22). The respondents were asked whether evolution only, creationism only, both, or neither were taught in high school (Additional file 2, question \#32) and what they thought should be taught in public science classrooms as asked by the Harris poll in 2005 (Additional file 2, question \#23). Students were also asked to identify their major (Additional file 2, question \#27), and responses were combined into either "science" (biology, chemistry, physics, psychology, anthropology, geography or geology) or "non-science" (any engineering major, history, theatre, music, communication, business, law, etc.). For the online surveys, each answered questionnaire automatically included additional information on the specific major of the respondent; this information was summarized in Additional file $3 \mathrm{~b}$ and $3 \mathrm{c}$ for a more detailed list of what majors were included in the science vs. non-science categories. Respondents were asked to identify their religion (Additional file 2, question \#29), and these were summarized into "Religious" (includes Southern Baptist and other Protestant denominations and Catholic), "Religious - Not Christian" (includes Jewish, Muslim, Hindu, etc.), and "Not Religious" (agnostic or atheist). A separate question addressed religious commitment and importance (Additional file 2, question \#30) by quantifying attendance at religious services; we use this as a measure of "religiosity". Several demographic questions were also included.

\section{Statistics}

All analyses were done using $\mathrm{R}$ version 3.0.3 ( $\mathrm{R}$ Core Team 2014). We used a structural equation model (SEM) using the lavaan package (Rosseel 2012) to determine how the following factors influence the latent variable "evolution understanding": 1) religion (Christian, Non-Christian but religious, or not religious), 2) religiosity (how often you attend religious services), 3) academic level (freshman, sophomore, junior, senior), 4) high school experience (whether you were taught evolution, creationism, neither, or both), and 5) your college major (science vs. nonscience). Because these variables are categorical, we $a$ priori defined each as either ordinal (religion, religiosity, academic level, and high school) or binomial (college major; Additional file 4). We defined "evolution understanding" as a latent variable measured by students' acceptance (MATE score - Additional file 2, questions \#1-20) and knowledge (KEE score - Additional file 2, questions \#33 and \#34) of evolution. We indirectly scaled this latent variable by fixing the MATE score factor loading to one. We examined all variables for skewness and kurtosis, and because many of our variables showed deviations from normality we fit our model with an asymptotic free distribution (Browne 1984). We regressed the "evolution understanding" latent variable against our five variables (i.e., religion, religiosity, academic level, high school experience, and major) and 
assessed model fit using multiple indices including the adjusted goodness-of-fit index (AGFI; Jöreskog and Sörbom 1983), a comparative fit index (CFI; Bentler 1990), Tucker-Lewis index (TLI; Hu and Bentler 1999), and the root mean squared error (RMSE) with 90\% confidence intervals (Browne and Cudeck 1993; MacCallum and Austin 2000). We determined significance of parameter estimates using a Wald statistic. We report all parameter estimates within the text as standardized estimates to allow comparison among factors.

To determine if students' acceptance of evolution, as measured by MATE score, relates to their knowledge of evolution (hereafter referred to as "knowledge score"), we used an ordinal regression with knowledge score as an ordered response (i.e., $0,1,2)$ and MATE score as the explanatory variable. We assessed the fit of this model using a likelihood ratio test with a model having no explanatory variable and then determined the $95 \%$ confidence interval for the model coefficient $\left(\beta_{\mathrm{MATE}}\right)$. Additionally, we used Kruskal Wallis tests to determine the relationship between MATE score and academic level, college major, high school experience, religion, and religiosity. We used the pgirmess package (Giraudoux 2013) for post hoc comparisons of the observed and critical differences among factor levels. We used a chi-squared test to compare what students believe should be taught in high school based on their high school experience.

\section{Pre-Post Comparison}

We surveyed three undergraduate introductory classes in the Department of Biological Sciences: Non-Majors Introductory Biology, Honors Introductory Biology, and Human Anatomy and Physiology. These courses differ in the following ways. Non-Majors Introductory Biology classes are not open to biology majors or minors or pre-health professionals students. Honors Introductory Biology courses are open to students who are seeking a major or minor in biology or a science related field, and students must have a membership in the University Honors Program. Human Anatomy and Physiology requires one semester of biology (either for majors or non-majors) and two semesters of chemistry. This course is designed for pre-health students.

We gave the identical survey before (pre) and at the very end (post) of the class to determine the extent views change. For this data set, we eliminated surveys in the same manner as done for the university-wide data set for a total of 487. All surveys were anonymous, so we match responses by class not individual. We used Kruskal-Wallis tests to determine if the mean MATE score differed among the pre and post surveys within each of the three university classes and within each of the three religiosity levels (among classes).

\section{Relationships between State K-12 Science Standards, State Religiosity, and State Educational Attainment}

To examine the degree of correlation between state science standard grades and state religiosity and educational attainment, we took data from the Pew Forum on Religion and Public Life Project's Religious Landscape Survey (Lugo et al. 2008) (http://religions.pewforum.org/) and the U.S. Census Bureau for 2009 (www.census.gov). We extracted data from all sources over the same general time frame for consistency across data sets (2008-2009). We compared each state's \% evangelicals, \% religion is "very" important to you, \% word of God is literally true word for word, and \% with at least once a week attendance at religious services with the state's K-12 science standards' numerical grade as given by Mead and Mates (2009). We also examined the number of bachelor degrees and number of advanced degrees per state and compared this to each state's K-12 science standards. We used those two measures of educational attainment since they were the most strongly correlated with acceptance of evolution in Heddy and Nadelson's (2013) state-by-state assessment of variables related to public acceptance of evolution. Numerical grades were squared to ensure normality, and then correlations were run.

\section{Results}

\section{Demographics}

We received a total of 2,999 responses for the full survey and of these $20 \%$ were from freshmen, $28 \%$ sophomores, $26 \%$ juniors, and $26 \%$ seniors. Thirty-three percent were science majors and $67 \%$ non-science majors (see Additional file 3 for break-down of specific majors in each category). Most of the science majors were biology majors (44\%), followed by psychology (23\%), and chemistry (10\%). Most of the non-science majors were from business (27\%), engineering (18\%), and humanities (17\%). The vast majority of respondents (74\%) have lived only in the southeastern United States (Florida, Alabama, Mississippi, Georgia, Louisiana, Tennessee, Virginia, Kentucky). Seventy-six percent of students are Christian, 3\% nonChristian but religious, and $21 \%$ are not religious (agnostic or atheist) (Table 1). Thirty-two\% of the respondents attend a religious service weekly, 26\% nearly weekly/ monthly, and $42 \%$ seldom/never.

\section{The Structural Equation Model ("Understanding" as a} latent variable combining "acceptance" and "knowledge") The SEM provided a good fit to our data (AGFI = 0.987; $\mathrm{CFI}=0.994 ; \mathrm{TLI}=0.983 ; \mathrm{RMSE}=0.036 ; 90 \% \mathrm{CI}=0.021$ 0.053). Higher levels of religiosity, defined as the level of attendance at religious services, $(\mathrm{r}=-0.391 ; \mathrm{z}=-22.280$; $\mathrm{P}<0.001)$ and identifying as a Christian $(\mathrm{r}=-0.316$; $\mathrm{z}=-23.348 ; \quad \mathrm{P}<0.001)$ negatively impacted students' understanding of evolution (Figure 1; Tables 2 and 3). On 
Table 1 Respondents' religious identities

\begin{tabular}{lll}
\hline Religious category & Religion & N (\%) \\
\hline Religious & Catholic & $378(12 \%)$ \\
& Other Protestant & $1,133(38 \%)$ \\
& Southern Baptist & $771(26 \%)$ \\
Religious - Not Christian & Jewish & $28(1 \%)$ \\
& Other $^{2}$ & $50(2 \%)$
\end{tabular}

Not Religious

$620(21 \%)$

1Other Protestant: Other Protestant denominations besides "Southern Baptist" included Methodist, Presbyterian, Episcopalian, Church of Christ, etc.

${ }^{2}$ Muslim, Hindu, etc.

the other hand, academic level $(\mathrm{r}=0.033 ; \mathrm{z}=2.298$; $\mathrm{P}=0.022)$, major $(\mathrm{r}=0.095 ; \mathrm{z}=6.836 ; \mathrm{P}<0.001)$, and what was taught in high school $(\mathrm{r}=0.117 ; \mathrm{z}=8.042 ; \mathrm{P}<0.001)$ positively affected students' understanding of evolution (Figure 1; Tables $2 \&$ 3). Additionally, our results show that the relative importance of either of the variables associated with religion is greater than all the variables associated with education for predicting students' evolution understanding (Figure 1; Tables $2 \& 3$ ).

\section{MATE ("acceptance") and KEE ("knowledge")}

To assess the construct validity of the MATE for our population, we used factor analysis to examine whether the 20 questions (Additional file 2, questions \#1-20) addressed a single psychological construct (e.g., "acceptance") or multiple ones (e.g., Rutledge and Sadler 2007; Rutledge and Warden 1999). We found that a single factor best explained our data. Factor 1 explained $62 \%$ of the variance, and adding a second factor explained only an additional
5.5\%. All questions except two (\#5 and \#17 - scientific community's views) achieved factor loading values greater than 0.65. Internal consistency measures (e.g., Chronbach's alpha) also examine the extent that questions are related and likely to measure a single psychological construct (see Rutledge and Sadler 2007). All alphas were above 0.96, indicating a high degree of internal consistency (Ruth 1994). This supports our contention that the MATE measures "acceptance" in our population. See Additional file 5 for details.

We also examined whether "acceptance" was related to "knowledge" of evolution. We found that students who had a higher acceptance of evolution (i.e., higher MATE score) tended to have higher knowledge scores on the KEE portion of the survey (Additional file 2, questions \#33 and \#34) (LRT $=669.63 ; \mathrm{df}=1 ; \mathrm{P}<0.001 ; \beta_{\text {MATE }} 95 \%$ $\mathrm{CI}=0.042-0.049$; Additional file 6). But because our survey included only two KEE questions and the scores from the KEE and MATE were positively associated, we decided to use only MATE score as the response variable in the rest of the analyses.

\section{Education: Major, Academic Level, and High School}

Acceptance of evolution increases as students further their tenure at university $\left(\chi^{2}=32.418 ; \mathrm{df}=3 ; \mathrm{P}<0.001\right.$; Figure 2a); science majors have significantly higher MATE scores at all academic levels $\left(\chi^{2}=37.994 ; \mathrm{df}=1\right.$; $\mathrm{P}<0.001$; Figure 2a). Regardless of major, when we look across academic levels and compare levels of acceptance of evolution for students that had different educational experiences in high school, we see a striking pattern (Figure 2b). Freshmen college students who were taught evolution in high school have the highest acceptance,

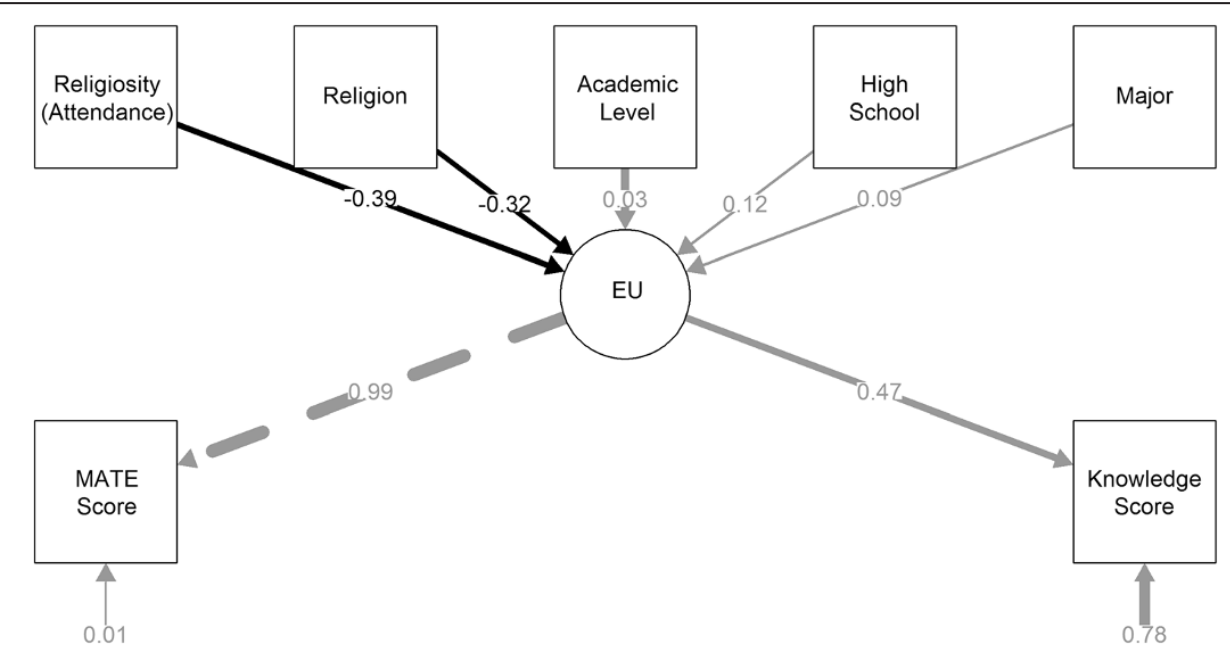

Figure 1 Structural equation model (SEM) of evolution understanding. Evolution understanding, a latent variable, is measured by MATE score and knowledge score, and then regressed against the five predictor variables: religion, religiosity (attendance), academic level, high school experience, and college major. Numbers show the standardized parameter estimates; black denotes negative relationships while gray denotes positive relationships. Dashed line represents fixed factor loading to one for MATE score. Complete parameter estimate information can be found in Table 2. 
Table 2 Parameter estimates for SEM

\begin{tabular}{|c|c|c|c|}
\hline Parameter estimate & Unstandardized (SE) & Standardized & Statistics \\
\hline \multicolumn{4}{|l|}{ Measurement Model Estimates } \\
\hline Evolution Understanding $\rightarrow$ MATE score & 1.00 & 0.993 & \\
\hline Evolution Understanding $\rightarrow$ Knowledge score & $0.471(0.023)$ & 0.469 & $z=20.674 P<0.001$ \\
\hline Error In MATE score & $0.013(0.038)$ & 0.013 & \\
\hline Error in Knowledge score & $0.777(0.018)$ & 0.780 & \\
\hline \multicolumn{4}{|l|}{ Structural Model } \\
\hline Religiosity $\rightarrow$ Evolution Understanding & $-0.389(0.017)$ & -0.391 & $z=-22.280 P<0.001$ \\
\hline Religion $\rightarrow$ Evolution Understanding & $-0.314(0.013)$ & -0.316 & $z=-23.348 P<0.001$ \\
\hline Academic Level $\rightarrow$ Evolution Understanding & $0.033(0.014)$ & 0.033 & $z=2.298 P=0.022$ \\
\hline High School $\rightarrow$ Evolution Understanding & $0.117(0.015)$ & 0.117 & $z=8.042 P<0.001$ \\
\hline Major $\rightarrow$ Evolution Understanding & $0.094(0.014)$ & 0.095 & $z=6.836 P<0.001$ \\
\hline Residual of Evolution Understanding & $0.555(0.041)$ & 0.561 & \\
\hline
\end{tabular}

Model was based on the responses of 2,920 students - those with fully completed surveys. Standard errors are shown for unstandardized parameter estimates in parentheses.

and this MATE score is higher than scores for students that were taught a) neither evolution or creationism, b) both evolution and creationism, or c) only creationism. In fact those students that were taught only evolution in high school outperform all others irrespective of academic level except as seniors when the students that were taught neither evolution nor creationism reach the same acceptance level; this level is significantly higher than that of students who were taught creationism or both creationism and evolution $\left(\chi^{2}=129.843 ; \mathrm{df}=3 ; \mathrm{P}<0.001\right.$; Figure $2 \mathrm{~b}$ ). Those taught creationism or both creationism and evolution have significantly lower acceptance of evolution at all academic levels (Figure 2b).

What college students were taught in high school also influences their views on what should be taught in high school $\left(\chi^{2}=191.23, \mathrm{df}=6, \mathrm{P}<0.001\right.$; Table 4$)$. The majority (over 60\%) of students in both science and non-science majors who were taught both creationism and evolution believe that both evolution and intelligent design should be taught in schools, and students who were taught only creationism also tended to prefer that both should be taught (Table 4). Although a relatively greater proportion of the students who were taught only evolution in high school thought just evolution should be taught, this group was still split between preferring only evolution (44\%) or both evolution and intelligent design (47\%) (Table 4).

\section{Religion and Religiosity (Attendance)}

The difference in acceptance of evolution for religious versus not religious individuals is significant $\left(\chi^{2}=919.21\right.$; $\mathrm{df}=1 ; \mathrm{P}<0.001$; Figure 3a). MATE scores for religious students were 28 points lower (mean $=62.90 ; \mathrm{SD}=19.42$ ) than not religious students (mean $=90.93 ; \mathrm{SD}=9.60$ ). Religiosity also makes a profound difference in acceptance of evolution $\left(\chi^{2}=990.54 ; \mathrm{df}=2 ; \mathrm{P}<0.001\right.$; Figure $\left.3 \mathrm{~b}\right)$. When we look within religiosity, science majors always

Table 3 Correlation matrix and descriptive statistics for variables included in SEM

\begin{tabular}{|c|c|c|c|c|c|c|c|}
\hline & MATE score & Knowledge score & Attendance & Religion & Academic level & High school & Major \\
\hline MATE Score & - & & & & & & \\
\hline Knowledge Score & 0.459 & - & & & & & \\
\hline Religiosity (Attendance) & -0.578 & -0.269 & - & & & & \\
\hline Religion & -0.544 & -0.253 & 0.540 & - & & & \\
\hline Academic Level & 0.094 & 0.044 & -0.080 & -0.088 & - & & \\
\hline High School & 0.208 & 0.097 & -0.128 & -0.127 & 0.021 & - & \\
\hline Major & 0.166 & 0.054 & -0.030 & -0.027 & -0.004 & 0.006 & - \\
\hline Mean & 69.16 & 1.27 & 1.91 & 2.56 & 2.58 & 3.07 & 0.33 \\
\hline SD & 21.04 & 0.74 & 0.86 & 0.81 & 1.08 & 0.99 & 0.47 \\
\hline Skewness & -0.29 & -0.48 & 0.18 & -1.34 & -0.07 & -0.48 & 0.73 \\
\hline Kurtosis & -0.98 & -1.06 & -1.61 & -0.14 & -1.27 & -1.21 & -1.47 \\
\hline
\end{tabular}

Correlation coefficients are listed for the seven variables of interest. The mean value, standard deviation (SD), skewness, and kurtosis for each variable are also provided. 


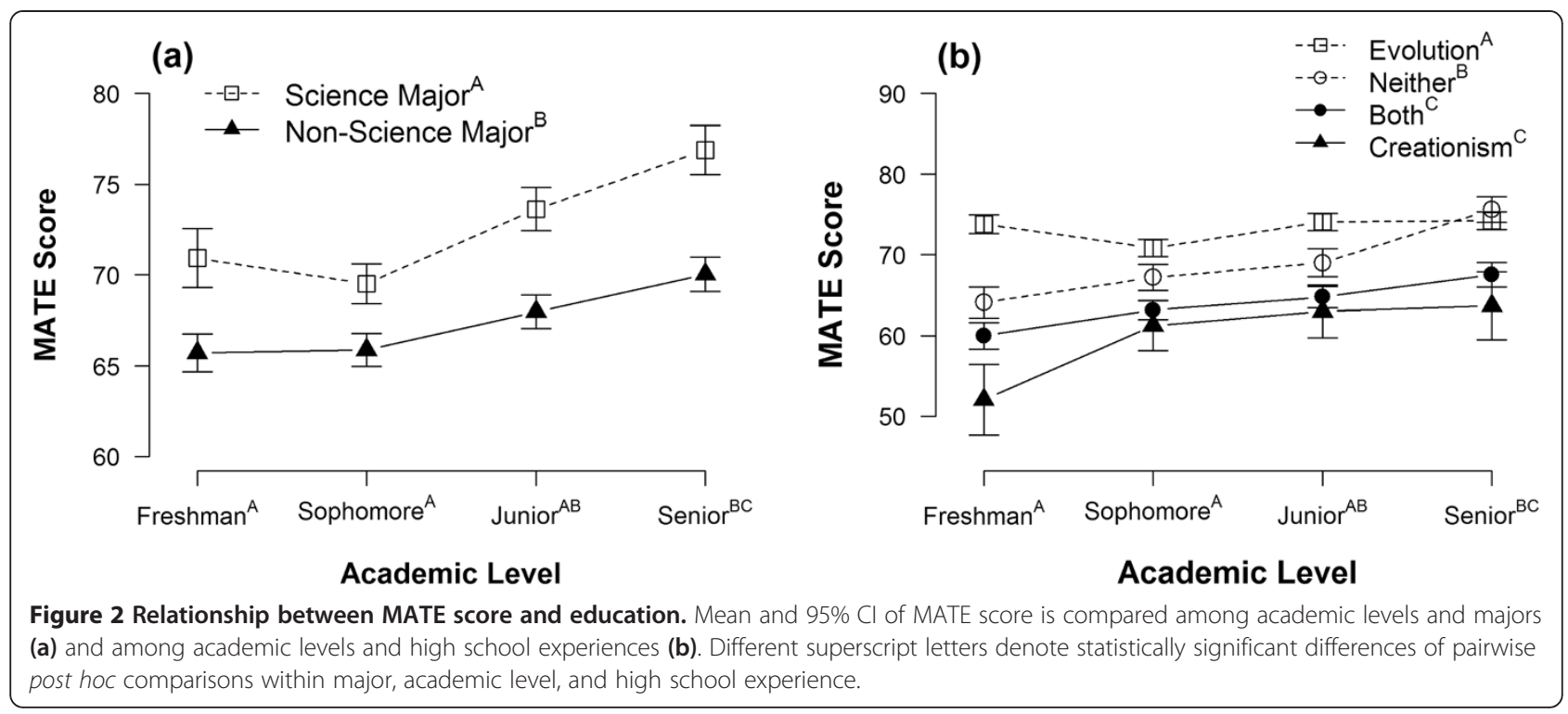

have higher acceptance, but not by much (only about 5 points) (Figure $3 \mathrm{~b}$ ). However, across religiosity levels, science majors who attend weekly religious services score, on average, $58.76(\mathrm{SD}=18.59)$, while students who seldom or never attend religious services score $84.93(\mathrm{SD}=14.69)$ (Figure $3 \mathrm{~b}$ ). Similarly, the non-science majors who attend weekly services scored, on average, 52.34 $(\mathrm{SD}=18.41)$, while those who seldom or never attend these services scored 81.13 (SD = 15.90) (Figure 3b).

When we investigated answers to the only two questions on the MATE (\#5 and \#17, Additional file 2) that specifically address how the "scientific community", rather than the student, views evolution, we found an interesting pattern (Figure 4; Additional file 7). Religious students score significantly lower (incorrectly) on the question "Most scientists accept evolutionary theory to be a scientifically valid theory" than students that are not religious $\left(\chi^{2}=168.680 ; \mathrm{df}=1 ; \mathrm{P}<0.001\right.$; Figure $\left.4 \mathrm{a}\right)$, as well as on the question "Much of the scientific community doubts if evolution occurs" $\left(\chi^{2}=408.450 ; \mathrm{df}=1 ; \mathrm{P}<0.001\right.$;
Figure 4c). However, the more striking result is the difference between scores on the analogous questions in a pair (e.g., \#5 vs \#10 and \#17 vs 6; Figure 4b and 4d, respectively) where a respondent in one question (e.g., \#5) is asked to indicate what the "scientific community" believes, and in a second question (e.g., \#10) what the student believes. If students do not accept evolution because of their faith rather than a lack of comprehension (e.g., Kahan 2014b), then we predicted highly religious students to score lower than less religious students on the questions from the student perspective but not, necessarily, on the questions asking for the scientific community's perspective. This would indicate that students understood the science, or at least knew what scientists believed, and their rejection of evolution was not simply due to lack of knowledge (Kahan 2014b). This is exactly what we see (Figure 4; Additional file 7). The questions asking for the scientific community's perspective do not differ very much across religiosity levels [0.450 increase (\#5); 0.587 increase (\#17); Figure $4 \mathrm{~b}$ and $4 \mathrm{~d}$, respectively]; however, the analogous

Table 4 Students' opinion of what should be taught based on their high school experience

\begin{tabular}{|c|c|c|c|}
\hline \multirow[t]{2}{*}{ What was taught in high school? } & \multicolumn{3}{|c|}{ What should be taught in high school? $\left(\frac{\text { Observed }(\%)}{\text { Expected }}\right)$} \\
\hline & Evolution Only ${ }^{1}$ & ID Only ${ }^{2}$ & Both \\
\hline Creationism & $\frac{36(26 \%)}{46}$ & $\frac{36(26 \%)}{20}$ & $\frac{67(48 \%)}{72}$ \\
\hline Both & $\frac{136(17 \%)}{263}$ & $\frac{145(18 \%)}{115}$ & $\frac{507(64 \%)}{410}$ \\
\hline Evolution & $\frac{551(44 \%)}{418}$ & $\frac{116(9 \%)}{182}$ & $\frac{586(47 \%)}{652}$ \\
\hline Neither & $\frac{138(34 \%)}{134}$ & $\frac{80(20 \%)}{59}$ & $\frac{184(46 \%)}{209}$ \\
\hline
\end{tabular}

"Evolution Only: "Evolution says that human beings evolved from earlier stages of animals."

2Intelligent Design (ID) only: "Intelligent design says that human beings are so complex that they required a powerful force or intelligent being to help create them." Number and percentages of students observed in each category are shown above with expected number of students for that category shown below horizontal lines. 
(a)

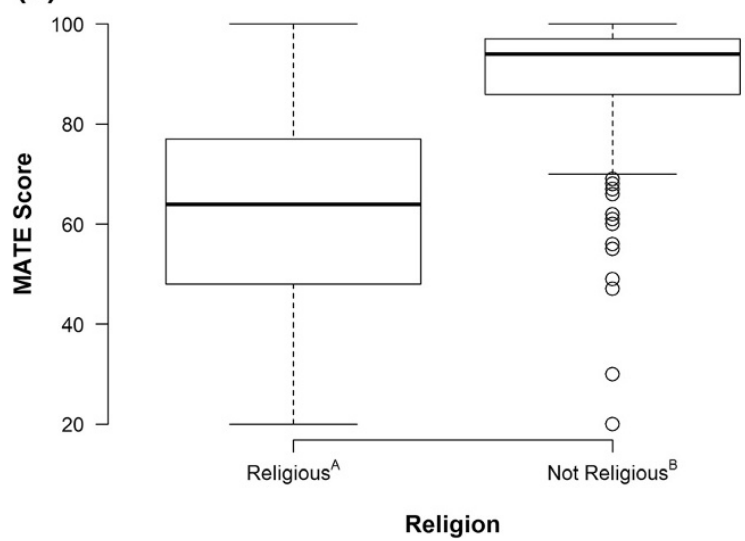

(b)

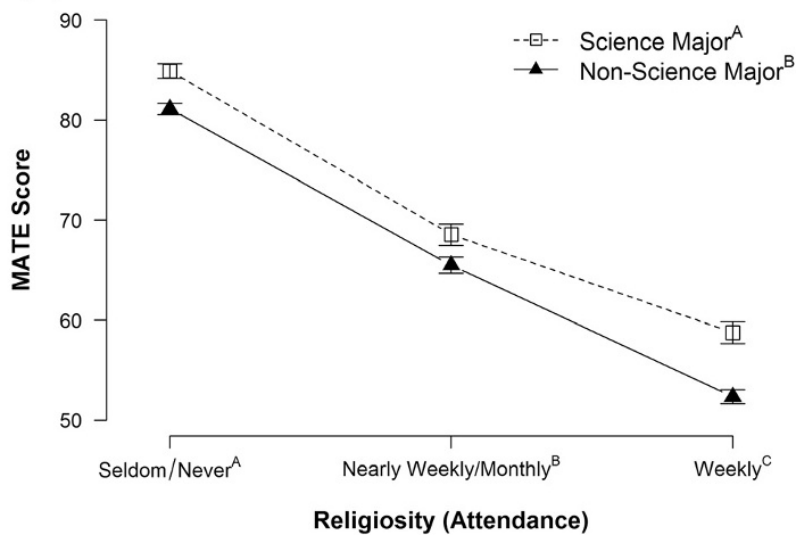

Figure 3 Relationship between MATE score and religiosity. Mean MATE score is compared among religious (Christians) and not religious students (a) and among religious attendance levels and majors (b). Different superscript letters denote statistically significant differences among levels based on post hoc comparisons.

\section{(a)}

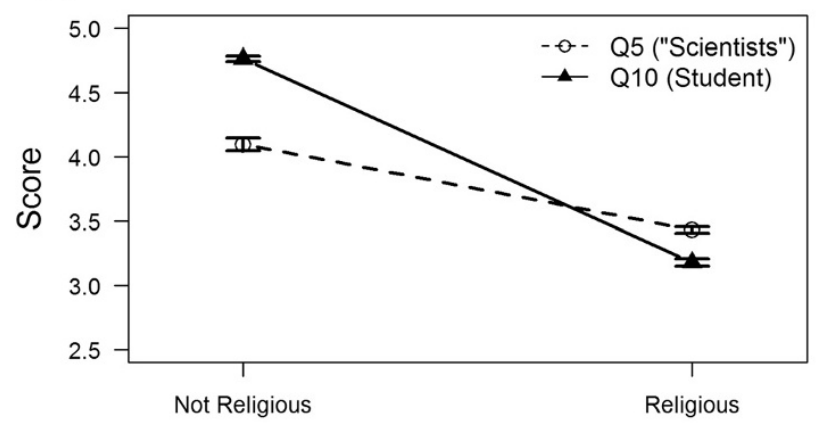

(b)

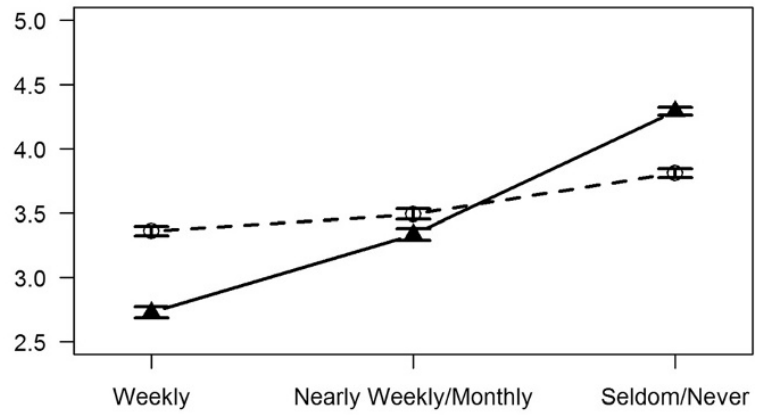

Q5 - "Most scientists accept evolutionary theory to be a scientically valid theory" Q10 - "Evolution is not a scientifically valid theory"

(c)

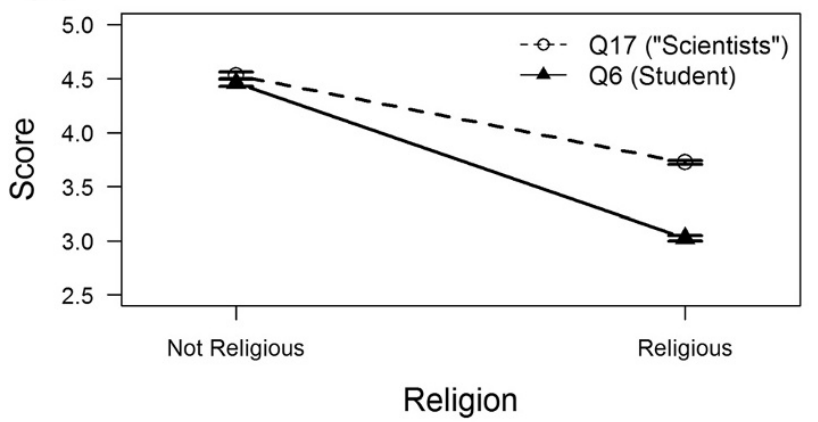

(d)

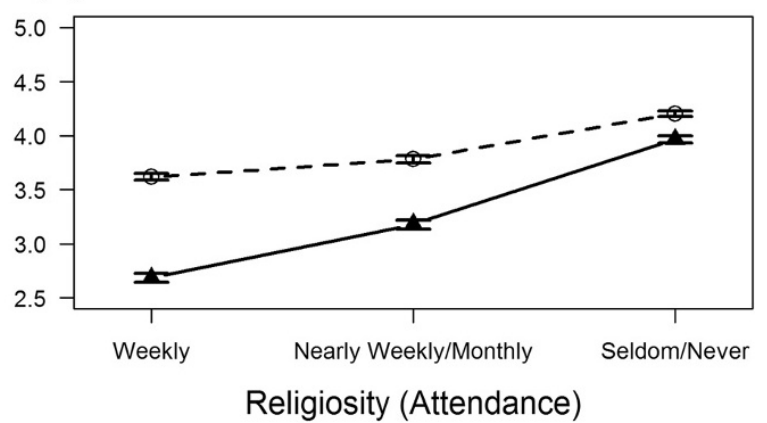

Q17 - "Much of the scientific community doubts if evolution occurs"

Q6 - "The available data are ambiguous (unclear) as to whether evolution actually occurs"

Figure 4 Comparisons of responses to questions on evolution if posed from the scientific community's ("scientists") vs. student perspectives. Mean and 95\% Cl for the score for scientists' views of evolution (Q5 and Q17; open circles, dashed lines) and student's views of evolution (Q10 and Q6; closed triangles and solid lines) are compared among religious (Christians) and not religious students (a, c), and across religious attendance levels $\mathbf{( b ,} \mathbf{d})$. Detailed statistics can be found in Additional file 7 . Note that all answers are scored according to Appendix $B$ of Rutledge and Sadler (2007) so that correct answers are closer to 5 and incorrect answers closer to 0. 
questions asking for the student's perspective differ more markedly [1.565 increase (\#10); 1.280 increase (\#6); Figure 4b and Figure 4d, respectively].

\section{Pre-Post Comparisons}

Two of the three classes had significantly higher acceptance of evolution in the post course survey (Table 5); pre and post surveys in Anatomy and Physiology did not differ (Table 5). When we examined whether the improvement of MATE scores differed according to religiosity, we found that the only students that significantly improved in the post course surveys, irrespective of class, were those that seldom/never attended religious services $\left(\chi^{2}=9.182\right.$; $\mathrm{df}=1 ; \mathrm{P}=0.002$; Figure 5).

\section{Relationships between State K-12 Science Standards, State Religiosity, and State Educational Attainment}

All state religiosity measures, except the percent with at least once a week attendance at religious services $(\mathrm{t}=-1.807 ; \mathrm{df}=48 ; \mathrm{P}=0.077 ; \mathrm{r}=-0.252)$, were significantly and negatively correlated with state $\mathrm{K}-12$ science standards' grades (Figure 6). The strongest correlation with quality standards was the percent evangelicals $(t=-3.336$; $\mathrm{df}=48 ; \mathrm{P}=0.002 ; \mathrm{r}=-0.434)$. Additionally, the percent of individuals in each state who think religion is "very" important $(\mathrm{t}=-2.426 ; \mathrm{df}=48 ; \mathrm{P}=0.019 ; \mathrm{r}=-0.330)$ and the percent that believe the word of God is literally true word for word $(\mathrm{t}=-3.234 ; \mathrm{df}=48 ; \mathrm{P}=0.002 ; \mathrm{r}=-0.423$ ) were both negatively correlated with the quality of science standards. For education, both measures were significantly and positively correlated with the standards (Figure 6). Higher numbers of bachelor degrees $(t=2.771 ; \mathrm{df}=48$; $\mathrm{P}=0.008 ; \mathrm{r}=0.371)$ and advanced degrees $(\mathrm{t}=2.220$; $\mathrm{df}=48 ; \mathrm{P}=0.031 ; \mathrm{r}=0.305)$ were associated with higher state science standards.

\section{Discussion}

Seventy-nine percent of our respondents in this large ( 35,000 undergraduates) public, southern university considered themselves religious, and of those, $76 \%$ are Christian. Twenty-one percent self-identified as not religious. Thirty-seven percent believe that all species, including humans, were created in their current form less than 10,000 years ago (young-earth creationists), while $40 \%$ accept evolution of all organisms with the caveat that God must have started the process. These figures are similar to Gallup polls over the last 30 years where $70-81 \%$ percent of Americans say religion is fairly to very important in their lives (Gallup Poll 2014b), and $42 \%$ - 46\% identify as young-earth creationists (Gallup Poll 2014a). In fact, 69\% of Americans who attend church weekly identify as young-earth creationists, and 67\% of our respondents did the same (Gallup Poll 2014a).

Whether a person is religious and how religious best explains what we term "evolution understanding" (Figure 1; Tables 2 \& 3). Structural equation modeling is a powerful approach to disentangling the importance of multiple, and often correlated, variables on a latent variable, in our case "evolution understanding" which contains information on acceptance of evolution and knowledge of evolution (Figure 1; Tables 2 \& 3). While education, both in high school and college, is important, the impact of religion and religiosity far outweigh education's influence (Figure 1). Science and non-science majors show similar patterns in their personal beliefs (Table 6). Students who are the most religious (attend a religious service weekly) overwhelmingly identify as creationists, but as religiosity declines, students shift to a more "ID" position where they accept evolution but believe that God must have started the process (Table 6).

In terms of acceptance of evolution, as students make academic progress, acceptance increases (Figure 2a, b) (Nadelson and Sinatra 2009; Sustersic 2007), but the degree of acceptance depends on both prior education in high school (Figure 2b; Moore and Cotner 2009; Moore et al. 2009; Schauer et al. 2014) and their degree of religiosity (Figure 3a, b). Science majors are more accepting of evolution, but both science and non-science majors improve as they further their tenure in college (Figure 2a). In fact we found that overall, seniors are less religious than freshman $\left(\chi^{2}=28.606 ; \mathrm{df}=2 ; \mathrm{P}<0.001\right)$, but it is only the non-science majors that shift from high religiosity (weekly attendance at religious services) as freshman to low religiosity (seldom/never attend religious services) as seniors $\left(\chi^{2}=27.763 ; \mathrm{df}=2 ; \mathrm{P}<0.001\right)$; science majors do not change $\left(\chi^{2}=2.460 ; \mathrm{df}=2 ; \mathrm{P}=0.292\right)$.

Table 5 Average MATE score between pre and post course surveys

\begin{tabular}{|c|c|c|c|}
\hline Class (N) & Mean pre course survey MATE score (SD) & Mean post course survey MATE score (SD) & Kruskal-Wallis test \\
\hline Non-Majors Intro Bio (138) & $62.27(14.93)$ & $74.58(15.13)$ & $\begin{array}{l}X^{2}=19.147 ; d f=1 \\
P<0.001\end{array}$ \\
\hline Honors Bio (41) & $69.48(17.48)$ & $84.69(14.34)$ & $\begin{array}{l}x^{2}=8.581 ; d f=1 \\
P=0.003\end{array}$ \\
\hline Anatomy \& Physiology (308) & $61.65(17.02)$ & $60.82(18.90)$ & $\begin{array}{l}x^{2}=0.122 ; d f=1 \\
P=0.727\end{array}$ \\
\hline
\end{tabular}




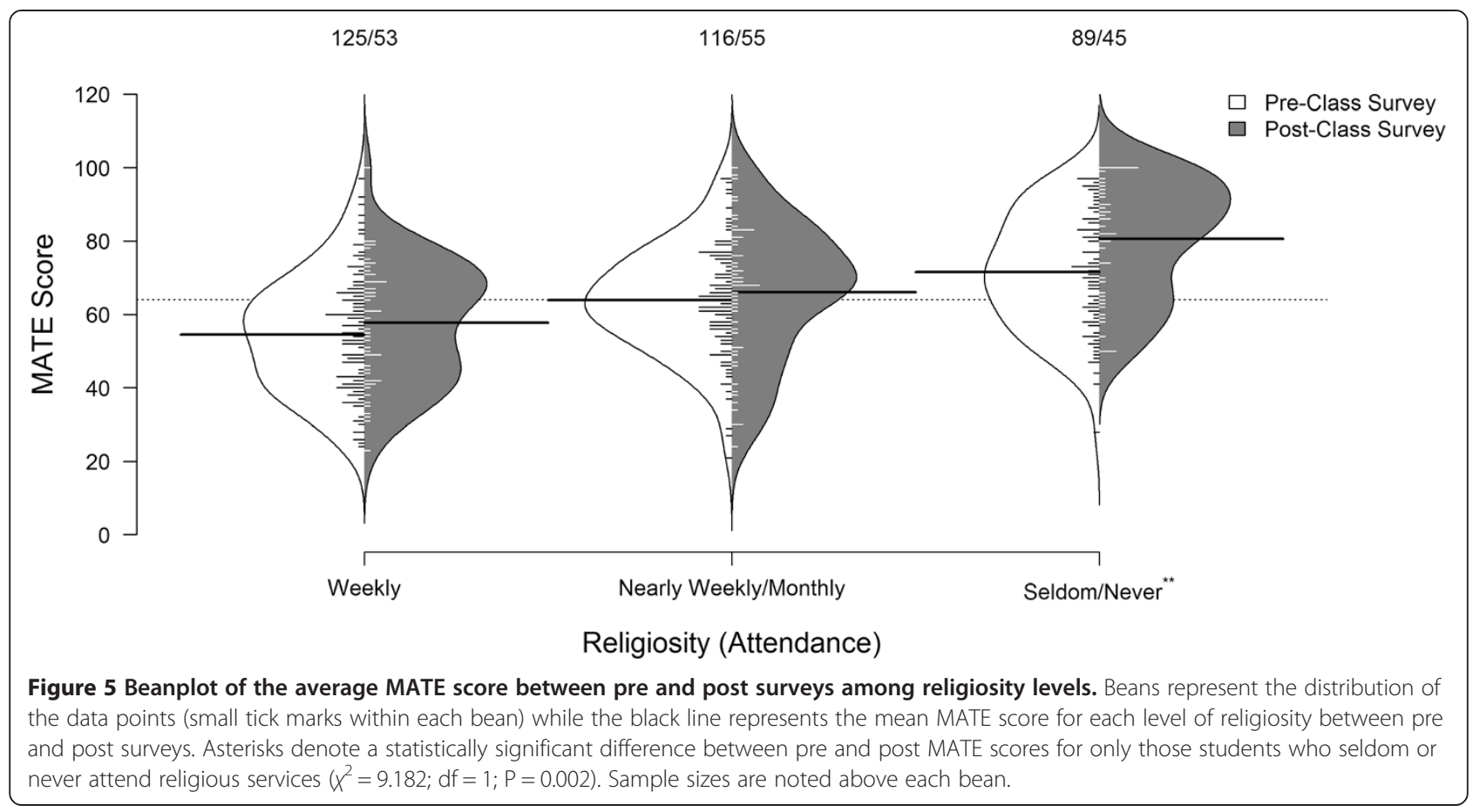

Students who are not religious are more accepting of evolution overall, and as religiosity increases, acceptance precipitously declines (Figure 3). In pre and post course assessments in basic biology courses, the least religious students were the only ones that showed an improvement in acceptance of evolution (Figure 5).
But how is acceptance of evolution related to knowledge of evolution and overall scientific literacy? Can we measure the differences, and does it matter? In a recent study Kahan (2014b) compared the relationship between a person's overall science comprehension taken from an 18-item test called the Ordinary Science Intelligence (a)

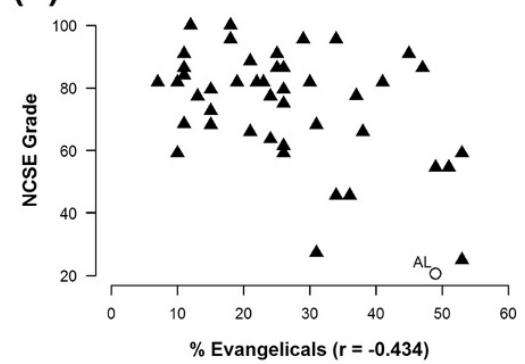

(d)

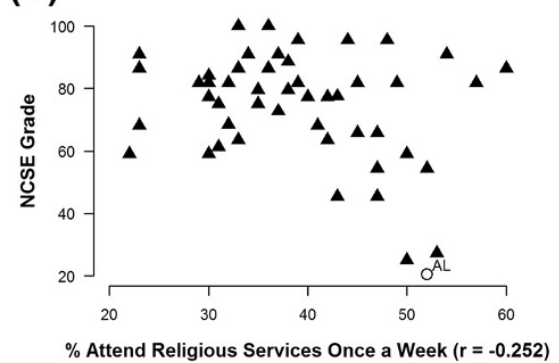

(b)

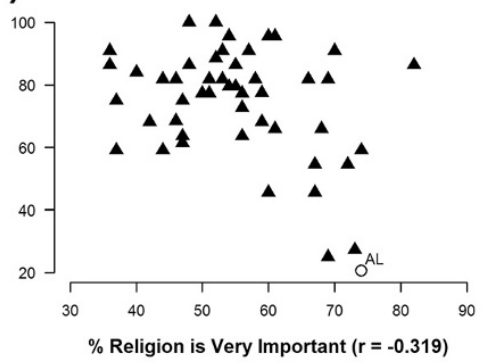

(e)

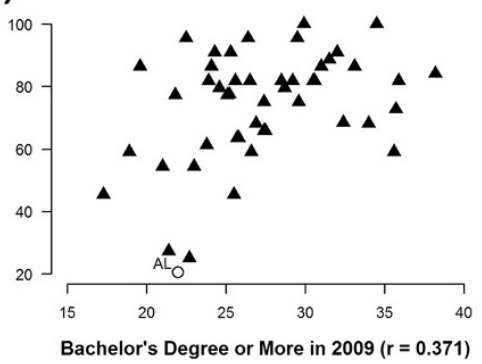

(c)

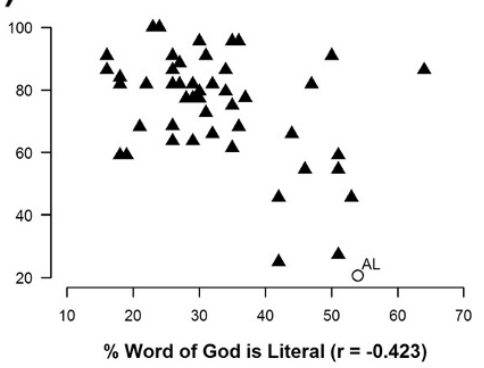

(f)

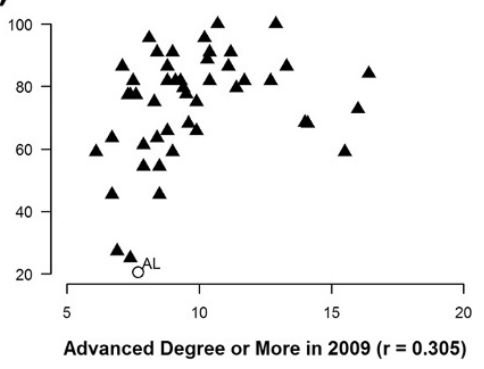

Figure 6 Correlations between state science standard grades, religiosity, and education. National Center for Science Education (NCSE) grades for K-12 state science standards (Mead and Mates 2009) are regressed against various measures of state religiosity (a-d) and state educational attainment (e-f). All correlations, shown in parentheses, were statistically significant $(P<0.05)$ except for the \% who attend religious services once a week $(P=0.077)$. Each triangle represents one state. Alabama is highlighted by the open circle. 
Table 6 Students' personal beliefs

\begin{tabular}{|c|c|c|c|c|c|}
\hline \multirow[b]{2}{*}{ Major } & \multirow[b]{2}{*}{ Religion } & \multirow[b]{2}{*}{ Religiosity (Attendance) } & \multicolumn{3}{|c|}{ Personal beliefs (\%) } \\
\hline & & & Creationism $^{1}$ & $I^{2}$ & Evolution $^{3}$ \\
\hline \multirow[t]{6}{*}{ Science Majors } & Religious & Seldom/Never & $33(18)$ & $122(67)$ & $26(14)$ \\
\hline & & Nearly Weekly/Monthly & $91(36)$ & $147(58)$ & $17(7)$ \\
\hline & & Weekly & $180(63)$ & $100(35)$ & $5(2)$ \\
\hline & Not Religious & Seldom/Never & $1(0)$ & $30(14)$ & $180(86)$ \\
\hline & & Nearly Weekly/Monthly & & $4(57)$ & $3(43)$ \\
\hline & & Weekly & & $1(100)$ & \\
\hline \multirow[t]{6}{*}{ Non-Science Majors } & Religious & Seldom/Never & $93(24)$ & $236(61)$ & $59(15)$ \\
\hline & & Nearly Weekly/Monthly & $200(43)$ & $239(52)$ & $21(5)$ \\
\hline & & Weekly & $455(69)$ & $195(30)$ & $8(1)$ \\
\hline & Not Religious & Seldom/Never & $1(0)$ & $52(14)$ & $325(86)$ \\
\hline & & Nearly Weekly/Monthly & & $2(17)$ & $10(83)$ \\
\hline & & Weekly & $1(33)$ & $1(33)$ & $1(33)$ \\
\hline
\end{tabular}

The number and percentage, in parentheses, of surveyed students who self-identified as believing in creationism, ID, or evolution is shown separately for different majors and religiosity levels. The patterns are the same for science and non-science majors.

${ }^{1}$ Creationism: "God created human beings in their present form at one time within the last 10,000 years or so." 2Intelligent Design (ID): "Human beings have developed over millions of years from less advanced forms of life, but God guided the process." "Evolution Only: "Human beings have developed over millions of years from less advanced forms of life, but God had no part in this process".

(OSI) scale (Kahan 2014a), to the probability of correctly responding to individual questions. Individual questions that are not positively correlated with overall OSI suggest bias - a systematic skew in one subgroup. The subgroup of interest in the Kahan study was the highly religious. In fact, Kahan (2014b) found that the probability of giving the correct response (true) on "Human beings, as we know them today, developed from earlier species of animals" was positively and strongly correlated with OSI only for less religious individuals; for the highly religious, there was no relationship. However, when asked the slightly different question "According to the theory of evolution, human beings, as we know them today, developed from earlier species of animals", the difference between highly religious and less religious respondents vanished. Kahan (2014b) concludes that many questions about "belief in evolution" or "acceptance" do not measure science comprehension or knowledge but rather incite a form of cultural identity that forces a person to choose between science and faith, because on almost all other science concepts posed by the OSI (e.g., electrons, atmospheric gases, probability, etc.), a person's degree of religiosity had little to do with the probability of a correct response, i.e., there was no bias.

Our results (Figure 4) support Kahan's thesis. Even though the MATE measures one construct ("acceptance"), we found two questions with low factor loadings in our validity tests (Additional file 4). These are the only two questions in the MATE that address what scientists believe, rather than what the student believes. Highly religious students should score significantly lower on the same question if asked to answer from the student's perspective rather than the scientific community's perspective; this pattern should not hold for the not religious students. This is exactly what we find (Figure 4). Results suggest that students reject evolution (i.e. fail to accept) because it conflicts with their faith even though they understand that the scientific community accepts evolutionary theory as valid. Whether this is directly related to knowledge is a bit less clear. In our study we had two questions from the KEE, and on both we found that religious students scored significantly lower than not religious students (only 33\% of the students who go to church weekly answered all KEE questions correctly, but $56 \%$ of students who seldom/never go to church did the same; Figure 4); if both groups of students had equal knowledge, this would seem unlikely. Kahan (2014b) also found a slightly negative correlation between religiosity and overall science literacy $(\mathrm{r}=-0.17, \mathrm{P}<0.01)$, and in a study by Moore et al. (2011), college students holding atheist/agnostic/no religious beliefs passed the KEE at rates approximately $150-200 \%$ higher than their more religious classmates. This suggests that it is not just "acceptance" that differs: religious students may not understand the science as well as their less religious cohort.

Students may ultimately reject evolution, then, because of a desire to protect cultural identities (e.g., Kahan 2014b) and/or adherence to a literalist, exclusivist religious schema (e.g., Hill 2011; Reimer 2010) rather than because of poor science education per se (e.g., Baker 2013; Mazur 2004). Across the United States, there is a strong and negative correlation between a literalist 
interpretation of the Bible and accepting evolution (Sherkat 2011). Over half (54\%) of Alabamians say that the scripture is the word of God, "literally word for word"; Mississippi is the only state with a higher percentage (64\%). In addition, eighty-six percent of Alabamians believe in God with "absolute certainty", according to the Pew Research Center's Religion and Public Life Project (Lugo et al. 2008), and if you add to that the percentage that is "fairly certain", $96 \%$ of the state agrees. The numbers for the rest of the U.S. are $71 \%$ and $88 \%$, respectively. The Deep South is also the bastion of evangelicals. Fortynine percent of Alabamians identify as evangelical protestant, while the rest of the U.S. is at $26 \%$. Only three states have higher percentages - Tennessee (51\%), Arkansas (53\%), and Oklahoma (53\%). At the opposite extreme, only $8 \%$ of the state is unaffiliated with a religion; this is exactly half of the average for the rest of the U.S. Does this strong religiosity of the Deep South impair science education, and if so, how?

While there is tremendous variability in the quality of K-12 science standards across the U.S. [low of $20.5 \%$ (F-) in Alabama to high of 100 (A) in New Jersey and California; Mead and Mates 2009], those states with high religiosity (Figure 6) have consistently low state science standard grades. While there are states with high grades despite having high religiosity (e.g., South Carolina and Utah), the states with the lowest grades all have high religiosity (Figure 6; Alabama, Louisiana, Oklahoma, Texas, and West Virginia). Educational attainment, on the other hand, is positively associated with higher standards (Figure 6). Clearly correlations do not, necessarily, imply causal relationships, and there could be other economic, political, or social factors that are equally or more important when predicting whether a state has high quality science standards. That said, many other studies show a negative relationship between religiosity and scientific education (Ecklund 2010; Heddy and Nadelson 2012; Larson and Witham 1997, 1998; Sherkat 2011), and with respect to evolution, there is a clear relationship between science literacy and acceptance of evolution at multiple levels (Heddy and Nadelson 2012; 2013; Nadelson and Sinatra 2009; Sustersic 2007). But it is unclear how these factors coalesce when state boards of education craft $\mathrm{K}-12$ science standards or appoint individuals to committees that develop them. As a case in point, Alabama has high religiosity, low educational attainment overall, and low science standards (Figure 6; Heddy and Nadelson 2013; Mead and Mates 2009). Since 1996, Alabama has included an evolution disclaimer in all public high school biology textbooks (Additional file 1). The decision to retain the disclaimer in 2001 and again in 2005 was actively supported by the Christian Coalition and the Eagle Forum, groups that seek more religious activity in public schools. Earlier versions stated that macroevolution is considered a "theory" and has never been observed, and that evolution "...refers to the unproven belief that random, undirected forces produced a world of living things". The current version (Additional file 1) does not include those statements but does, misleadingly, point out the word "theory" as having many meanings and being subject to change. The disclaimer also notes that while natural selection has been observed to influence small changes in populations it is only "assumed" to produce large changes, “... even though this has not been directly observed". Students are instructed to "...wrestle with the unanswered questions and unresolved problems still faced by evolutionary theory". While not overtly creationist in language, the disclaimer is likely to intimidate teachers, confuse students, and cause the omission and/or de-emphasis of evolution in life science coursework (Goldston and Kyzer 2009). It is possible, even likely, that disclaimers and poor science standards weaken science literacy of students, and as already mentioned, states with the highest religiosity and weakest science standards are also the ones with the lowest overall educational attainment (Figure 6).

Even though religion and religiosity strongly influence evolution understanding (Figure 1; Tables 2 \& 3), education also matters (Figure 2b). What students are taught in high school influences their acceptance of evolution and what they believe should be taught to future generations in high school (Table 4). In a review of empirical research studies on K-12 teachers regarding evolution, Sickel and Friedrichsen (2013) show that there are profound misconceptions about evolution that color how teachers present the topic and how much time they devote to evolution. The factor most often associated with a rejection of evolution is strength of religious convictions (Losh and Nzekwe 2011a,b; Sickel and Friedrichsen 2013; Trani 2004). For example, a recent study of women ( $\mathrm{n}=375$ females) in teacher education courses found that 93\% who view the Bible as the literal word of God also reject evolution, while $80 \%$ of those that view the Bible as a book of legends accept evolution (Levesque and Guillaume 2010). In Florida a study of K-12 science teachers $(\mathrm{n}=353)$ found a strong negative correlation between being "comfortable" with evolution and agreeing that a belief in God means rejecting evolution (Fowler and Meisels 2010). In several studies, including a national survey of 939 teachers (Berkman et al. 2008), $\mathrm{K}-12$ teachers tend to teach evolution not as a unifying theme but rather as a stand-alone unit focused on natural selection. Human evolution is often left completely out (Sickel and Friedrichsen 2013). In summary, our study and others suggest that there is a clash between faith and science, most likely between a faith-based vs. scientific view of the origin of species (Alters and Alters 2001; Coyne 2012; Kahan 2014b; Miller 2008; Nadelson and Sinatra 2009; Scott 2009). This clash causes 
individuals to cling to a cultural identity that, at least in the Deep South, eschews evolution. By so doing, religion can negatively impact education standards, science instruction, and ultimately knowledge.

Individuals can have a hard time reconciling their religious beliefs with particular scientific tenets, especially evolution (Alters and Alters 2001; Berkman et al. 2008; Berkman and Plutzer 2010; Coyne 2012; Masci 2007, 2009; but see Baker 2012). Approximately 35\% of the public believes that it is not possible to accept God and evolution (Plutzer and Berkman 2008), and 55\% of the public agreed that science and religion are often in conflict (Masci 2009). Interestingly, a recent study of eminent scientists in the Royal Society showed that about equal numbers of scientists agreed and disagreed with the statement that religion and science are non-overlapping domains of discourse and can peacefully coexist, $28.4 \%$ vs. $24.3 \%$, respectively; however, biological scientists were more likely to say they see a conflict between science and religion than physical scientists (Stirrat and Cornwell 2013). Elite scientists at both the National Academies of Science (Larson and Witham 1998) and the Fellows of the Royal Society (Stirrat and Cornwell 2013) overwhelmingly reject a belief in God - only about $8 \%$ of both groups indicated belief (Lugo et al. 2008). This is striking when compared to the general public where 95\% believe in God (Gallup and Lindsay 1999). This disparity between the degree of religiosity of scientists and the general public has been cited as evidence of the incompatibility of science and religion (Coyne 2012). In fact, when queried, about two-thirds of the public admitted that if they had to choose between accepting a scientific fact that went against their religious teachings and adhering to the scriptural view, they would reject the science (Masci 2007). However, many people and even scientific organizations make the case that to improve scientific literacy, one must endorse the view that evolution is not incompatible with religious faith - a position called "accomodationism" (reviewed in Coyne 2012). Heddy and Nadelson (2013) even state that there should be "...interventions to relieve the perceived conflict between religious worldviews and acceptance of evolution as a means of addressing the STEM employee shortage". While we do not agree that no conflicts exist between religious and purely scientific worldviews, given that many religious ideas are obviously in direct conflict with evolution (e.g., age of the earth), we believe that to improve scientific literacy, educators must focus on the science. K-12 science standards must be of the highest quality, for standards provide legitimacy and support for teachers, even when local opposition to evolution instruction is high (Goldston and Kyzer 2009; Moore and Kraemer 2005). They also provide some assurance that all students will be provided with a high quality science education, whether or not those students later choose to reject that knowledge because of faith (Kahan 2014b). Thus, the public must work hard to ensure that science, especially evolution, is not marginalized or left out of standards (Mead and Mates 2009), especially in states with high religiosity.

\section{Conclusions}

Religion and religiosity, not education, best explain university students' views on evolution in the Deep South. Our study was the first in-depth analysis $(n=2,999)$ of acceptance of evolution in this geographic region (Wagler and Wagler 2013) - an area of high religiosity and low educational attainment. We used SEM to examine how religion, religiosity, high school experience, college major, and academic level independently influence our latent variable ("evolution understanding") (Figure 1). We found that highly religious students are much less likely to accept evolution, irrespective of education, and that this rejection occurs even though they understand that the scientific community accepts the theory of evolution (Figure 4). In fact only the least religious students improved their acceptance in post-course assessments (Figure 5). That said, we do not have enough information to definitively state whether religious and not religious students differ in their knowledge of key facts about evolution, because we used only a limited number of questions from the KEE. It is likely, however, that the social and cultural context of student learning affects not only acceptance but also knowledge.

In areas of the country where the vast majority of residents believe in God and the literal truth of the Bible, students may enter college less prepared and more skeptical of science because of disclaimers or poor science standards that limit the quality and quantity of science education in high school (Bak 2001; Gauchat 2008, 2011, 2012; Sturgis and Allum 2004). In fact Southerners have lower levels of trust in science compared to other Americans (Gauchat 2012), and those who attend church frequently and are of a conservative political ideology are becoming even more distrustful of science through time (Gauchat 2012). This is a worrisome trend for those who hope for a scientifically literate society able to distinguish pseudoscience from science. Studies show that states and countries with higher levels of acceptance of evolution have higher GDP (Heddy and Nadelson 2012, 2013) and are more successful (Coyne 2012; Paul 2009; Solt et al. 2011). Those distrustful of science are being left behind, not just in understanding how the world works, but in the work that elevates world economies. Among scientists there can be debate about how to best combat the superstition, fear, and mistrust that feeds an anti-science bias. One thing is above debate: a nation where high science standards and excellent public education are 
universal will improve more than just the acceptance and knowledge of evolution; it will improve society and well-being for all.

\section{Additional files}

Additional file 1: Disclaimer. Alabama evolution disclaimer. Text of the evolution disclaimer placed in all public high school textbooks since 1996. This latest version was approved in 2005.

Additional file 2: Survey. Evolution survey. The survey that was administered to students at The University of Alabama.

Additional file 3: Majors. Breakdown of science and non-science majors. Percentages of science and non-science majors surveyed.

Additional file 4: Type and order of SEM variables. Type and order of explanatory variables for SEM. Explanation of the a priori ordering of the variables in the SEM.

Additional file 5: Factors and factor loadings. Validity and consistency measures. Eigenvalues and variance explained for the first four factors indicate one psychological construct best explains our data. Factor loadings and Chronbach's Alpha for questions indicate that these questions are measuring the same factor.

Additional file 6: Knowledge and MATE scores. Knowledge and acceptance of evolution. The conditional distribution of the knowledge score (based on two questions in the KEE) with the MATE score. A score of 0 (two incorrect answers) is black. A score of 1 (one incorrect answer) is dark gray. A score of 2 (zero incorrect answers) is white.

Additional file 7: Scientists vs Students. Results of Kruskal-Wallis tests comparing scores among religions (within questions), among religiosity (within questions), among questions (within religion) and among questions (within religiosity). For comparisons among religiosity (within questions) we used pairwise post hoc comparisons to determine significance among religiosity levels.

\section{Abbreviations}

AGFl: Adjusted goodness-of-fit; CFI: Comparative fit index; KEE: Knowledge of evolution exam; MATE: Measure of the acceptance of the theory of evolution; NCSE: National Center for Science Education; PISA: Programme for International Student Assessment; RMSE: Root mean squared error; SEM: Structural equation modeling (or Model); TLI: Tucker-Lewis index.

\section{Competing interests}

The authors declare that they have no competing interests.

\section{Authors' information}

LR is Professor of Biological Sciences and Co-Director of the Evolutionary Studies Minor at The University of Alabama (UA). She has taught the upper-level Evolution course at UA for approximately 10 years, and she chairs the Evolution Working Group on her campus. This group organizes and hosts the annual public ALLELE (ALabama LEctures on Life's Evolution) series at The University of Alabama (http://evolution.as.ua.edu).

\section{Authors' contributions}

LR designed the project, developed the survey, and wrote the first draft of the manuscript. SD helped with administering the survey to classes and summarizing the data. NC performed the statistical analyses and produced the tables and figures. All authors read, edited, and approved the final manuscript.

\section{Acknowledgements}

We thank John Acker for administering the online survey to students and Ashley Blalock for help with administering the survey to classes for the pre and post analysis. We also thank the faculty who allowed us to use some of their class time to administer the surveys. We thank Peter Scott, Roger Reid, and three anonymous reviewers for comments on earlier drafts of the manuscript. IRB protocol number 10-OR-074 titled "Origins of Life Perception Survey" was approved 24 March 2010 through The University of Alabama.
Received: 4 June 2014 Accepted: 10 September 2014

\section{Published online: 15 October 2014}

\section{References}

Aguillard, D. (1999). Evolution education in Louisiana public schools: a decade following: Edwards v Aguillard. Am Biol Teach, 61(3), 182-188.

Alters, BJ, \& Alters, S. (2001). Defending evolution in the classroom: A guide to the creation/evolution controversy. Sudbury, Massachusetts: Jones and Bartlett Publishing.

Alters, BJ, \& Nelson, CE. (2002). Perspective: Teaching evolution in higher education. Evolution, 56(10), 1891-1901.

Astin, AW, Astin, HS, Lindholm, JA, Bryant, AN, Calderon, S, \& Szelényi, D. (2005). The spiritual life of college students: A national study of college students' search for meaning and purpose. Los Angeles: Higher Education Research Institute.

Bak, HJ. (2001). Education and public attitudes toward science: Implications for the "deficit model" of education and support for science and technology. Soc Sci Q, 82(4), 779-795.

Baker, JO. (2012). Public perceptions of incompatibility between "science and religion.". Public Underst Sci, 21(3), 340-353.

Baker, JO. (2013). Acceptance of evolution and support for teaching creationism in public schools: The conditional impact of educational attainment. J Sci Study Relig, 52(1), 216-228.

Bandoli, JH. (2008). Do state science standards matter? Comparing student perceptions of the coverage of evolution in Indiana \& Ohio public high schools. Am Biol Teach, 70(4), 212-216.

Bentler, PM. (1990). Comparative fit indexes in structural models. Psychol Bull, 107(2), 238-246.

Berkman, MB, Pacheco, JS, \& Plutzer, E. (2008). Evolution and creationism in America's classrooms: a national portrait. PLoS Biol, 6(5), 920-924.

Berkman, M, \& Plutzer, E. (2010). Evolution, creationism, and the battle to control America's classrooms. Cambridge University Press. http://www.langtoninfo.co. uk/web_content/9780521148863_frontmatter.pdf. Accessed 20 April 2014.

Bishop, BA, \& Anderson, CW. (1990). Student conceptions of natural selection and its role in evolution. J Res Sci Teach, 27(5), 415-427.

Braden, L, Finn, CE, Lerner, LS, Munroes, S, Petrilla, MJ, Raimi, RA, Sake, DW, Smith, T, \& Stotsky, S. (2000). The state of state standards. In B Thomas (Ed.), The state of state standards. Fordham Foundation and Institute.

Browne, MW. (1984). Asymptotic distribution-free methods in the analysis of covariance structures. Br J Math Stat Psychol, 37(1), 62-83.

Browne, MW, \& Cudeck, R. (1993). Alternative ways of assessing model fit. In KA Bollen \& JS Long (Eds.), Testing structural equation models (pp. 445-455). Newbury Park: Sage.

Brumfiel, G. (2005). Intelligent design: Who has designs on your students' minds? Nature, 434(April), 1062-1065.

Chinsamy, A, \& Plagányi, E. (2008). Accepting evolution. Evolution, 62(1), 248-254.

Cotner, S, Brooks, DC, \& Moore, R. (2010). Is the age of the earth one of our "sorest troubles?" Students' perceptions about deep time affect their acceptance of evolutionary theory. Evolution, 64(3), 858-864.

Coyne, JA. (2012). Science, religion, and society: the problem of evolution in America. Evolution, 66(8), 2654-2663.

Ecklund, EH. (2010). Science vs. religion: What scientists really think. Oxford, U.K: Oxford University Press.

Fowler, SR, \& Meisels, GC. (2010). Florida teachers' attitudes about teaching evolution. Am Biol Teach, 72(2), 96-99.

Gallup Poll. (2014a). In U.S., 42\% hold creationist view of human origins. http://www.gallup.com/poll/170822/believe-creationist-view-humanorigins.aspx. Accessed 28 July 2014.

Gallup Poll. (2014b). Evolution, creationism, and intelligent design. http://www.gallup. com/poll/21814/evolution-creationism-intelligent-design.aspx. Accessed 31 July 2014

Gallup, G, \& Lindsay, GM. (1999). Surveying the religious landscape: Trends in US beliefs. Harrisburg, PA: Morehouse Publishing.

Gauchat, GW. (2008). A test of three theories of anti-science attitudes. Sociol Focus, 41(4), 337-357.

Gauchat, GW. (2011). The cultural authority of science: Public trust and acceptance of organized science. Public Underst Sci, 20(6), 751-770.

Gauchat, GW. (2012). Politicization of science in the public sphere, a study of public trust in the United States, 1974 to 2010. Am Sociol Rev, 77(2), 167-187.

Giraudoux, P. (2013). Pgirmess: Data Analysis in Ecology. R Package Version 1.5.8.

Goldhaber, D, \& Anthony, E. (2003). Indicators of teacher quality. ERIC Digest. http://files.eric.ed.gov/fulltext/ED478408.pdf. Accessed 25 April 2014. 
Goldston, MJ, \& Kyzer, P. (2009). Teaching evolution: Narratives with a view from three southern biology teachers in the USA. J Res Sci Teach, 46(7), 762-790.

Griffith, JA, \& Brem, SK. (2004). Teaching evolutionary biology: Pressures, stress, and coping. J Res Sci Teach, 41(8), 791-809.

Gross, PR. (2005). The state of state science standards, 2005. In B Thomas (Ed.), The state of state science standards, 2005. Fordham Foundation \& Institute. http://www.edexcellencemedia.net/publications/2005/ 200512_stateofstatestandards2005/Science\%20Standards.FinalFinal.pdf. Accessed 15 April 2014.

Heddy, BC, \& Nadelson, LS. (2012). A global perspective of the variables associated with acceptance of evolution. Evolution, 5(3), 412-418.

Heddy, BC, \& Nadelson, LS. (2013). The variables related to public acceptance of evolution in the United States. Evolution, 6(1), 3.

Hill, JP. (2011). Faith and understanding: Specifying the impact of higher education on religious belief. J Sci Study Relig, 50(3), 533-551.

Hu, LT, \& Bentler, PM. (1999). Cut-off criteria for fit indexes in covariance structure analysis: conventional criteria versus new alternatives. Structural Equation Modeling, 6(1), 1-55.

Ingram, EL, \& Nelson, CE. (2006). Relationship between achievement and students' acceptance of evolution or creation in an upper level evolution course. J Res Sci Teach, 43(1), 7-24.

Jöreskog, KG, \& Sörbom, D. (1983). LISREL-6 User's Reference Guide. Mooresville: Scientific Software.

Kahan, DM. (2014a). Ordinary Science Intelligence": A science comprehension measure for use in the study of risk perception and science communication. In Cultural Cognition Project Working Paper (112th ed.).

Kahan, DM. (2014b). Climate science communication and the measurement problem. Advances Pol Psych, Forthcoming. Available at SSRN: http://ssrn.com/abstract=2459057.

Larson, EJ, \& Witham, L. (1997). Belief in God and immortality among American scientists: A historical survey revisited. Nature, 386(April), 435.

Larson, EJ, \& Witham, L. (1998). Leading scientists still reject God. Nature, 394(July), 313.

Lawson, AE, \& Worsnop, WA. (1992). Learning about evolution and rejecting a belief in special creation: Effects of reflective reasoning skill, prior knowledge, prior belief and religious commitment. J Res Sci Teach, 29(2), 143-166.

Lerner, LS. (2000). Good and bad science in US schools. Nature, 407, 287-290.

Levesque, PJ, \& Guillaume, AM. (2010). Teachers, evolution, and religion: No resolution in sight. Rev Relig Res, 51(4), 349-365.

Losh, SC, \& Nzekwe, B. (2011a). The influence of education major: How diverse preservice teachers view pseudoscience topics. J Sci Educ Technol, 20(5), 579-591.

Losh, SC, \& Nzekwe, B. (2011 b). Creatures in the classroom: Preservice teacher beliefs about fantastic beasts, magic, extraterrestrials, evolution and creationism. Sci \& Educ, 20(5), 473-489.

Lugo, L, Stencel, S, Green, J, Smith, G, Cox, D, Pond, A, Miller, T, Podrebarac, E, Ralston, M, Kohut, A, Taylor, P, \& Keeter, S. (2008). US religious landscape survey: Religious affiliation-diverse and dynamic. The Pew Forum on Religion and Public Life. http://religions.pewforum.org/pdf/report-religious-landscapestudy-full.pdf. Accessed 12 April 2014.

MacCallum, RC, \& Austin, JT. (2000). Applications of structural equation modeling in psychological research. Annu Rev Psychol, 51(1), 201-226.

Masci, D. (2007). How the Public resolves conflict between faith and science. The Pew Forum on Religion and Public Life. http://www.pewforum.org/2007/08/ 27/how-the-public-resolves-conflicts-between-faith-and-science/. Accessed 13 April 2014

Masci, D. (2009). arwin debated: Religion vs. evolution. The Pew Forum on Religion and Public Life. http://www.pewresearch.org/2007/06/13/the-darwin-debate/. Accessed 13 April 2014

Mazur, A. (2004). Believers and disbelievers in evolution. Politics Life Sci, 23(2), 55-61.

Mead, LS, \& Mates, A. (2009). Why science standards are important to a strong science curriculum and how states measure up. Evolution, 2(3), 359-371

Meadows, L, Doster, E, \& Jackson, DF. (2000). Managing the conflict between evolution \& religion. Am Biol Teach, 62(2), 102-107.

Miller, JD, Scott, EC, \& Okamoto, S. (2006). Public acceptance of evolution. Science, 313(August), 765-766.

Miller, KR. (2008). Only a theory: Evolution and the battle for America's soul. New York: Penguin Group.

Moore, R. (2002). Teaching evolution: do state standards matter? Bioscience, 52(4), 378-381.
Moore, R. (2008). Creationism in the biology classroom: what do teachers teach \& how do they teach it? Am Biol Teach, 70(2), 79-84.

Moore, R, Brooks, DC, \& Cotner, S. (2011). The relation of high school biology courses and students' religious beliefs to college students' knowledge of evolution. Am Biol Teach, 73(4), 222-226.

Moore, R, \& Cotner, S. (2009). The creationist down the hall: does it matter when teachers teach creationism? Bioscience, 59(5), 429-435.

Moore, R, Cotner, S, \& Bates, A. (2009). The influence of religion and high school biology courses on students' knowledge of evolution when they enter college. J Effective Teach, 9(2), 4-12.

Moore, R, \& Kraemer, K. (2005). The teaching of evolution \& creationism in Minnesota. Am Biol Teach, 67(8), 457-466.

Nadelson, LS, \& Sinatra, GM. (2009). Educational professionals' knowledge and acceptance of evolution. Evol Psychol, 7(4), 490-516.

Council, NR. (2001). Testing teacher candidates: The role of licensure tests in improving teacher quality. Washington, DC: The National Academies Press.

Organisation for Economic Co-operation and Development (OECD). (2014). PISA 2012 results: What students know and can do - student performance in mathematics, reading and science (Ith ed.). PISA, OECD Publishing. http://dx.doi.org/10.1787/9789264201118-en. Accessed 23 April 2014.

Paul, G. (2009). The Chronic dependence of popular religiosity upon dysfunctional psychosociological conditions. Evol Psychol, 7(3), 98-441.

Paz-y-Mino, G, \& Espinosa, A. (2009). Acceptance of evolution increases with student academic level: a comparison between a secular and a religious college. Evolution, 2(4), 655-675.

Plutzer, E, \& Berkman, M. (2008). Trends evolution, creationism, and the teaching of human origins in schools. Public Opinion Quarterly, 72(3), 540-553

Core Team, R. (2014). R: a language and environment for statistical computing. Vienna: R Foundation for Statistical Computing.

Reimer, S. (2010). Higher education and theological liberalism: Revisiting the old issue. Sociol Relig, 71(4), 393-408.

Rosseel, Y. (2012). lavaan: an R package for structural equation modeling. J Stat Softw, 48(2), 1-36

Ruth, D. (1994). Practical statistics for educators. Lanham, MD: University Press of America.

Rutledge, ML, \& Sadler, KC. (2007). Reliability of the Measure of Acceptance of the Theory of Evolution (MATE) instrument with university students. Am Biol Teach, 69(6), 332-335.

Rutledge, ML, \& Sadler, KC. (2011). University students' acceptance of biological theories-is evolution really different? J Coll Sci Teach, 41(2), 38-43.

Rutledge, ML, \& Warden, MA. (1999). The development and validation of the measure of acceptance of the theory of evolution instrument. Sch Sci Math, 99(1), 13-18.

Rutledge, ML, \& Warden, MA. (2000). Evolutionary theory, the nature of science \& high school biology teachers: Critical relationships. Am Biol Teach, 62(1), 23-31.

Schauer, A, Cotner, S, \& Moore, R. (2014). Teaching evolution to students with compromised backgrounds \& lack of confidence about evolution-is it possible? Am Biol Teach, 76(2), 93-98.

Scott, EC. (2009). Evolution vs. creationism: an introduction. Berkely, California: University of California Press.

Sherkat, DE. (2011). Religion and scientific literacy in the United States. Soc Sci Q, 92(5), 1134-1150.

Sickel, AJ, \& Friedrichsen, P. (2013). Examining the evolution education literature with a focus on teachers: major findings, goals for teacher preparation, and directions for future research. Evolution, doi:10.1186/1936-6434-6-23.

Sinclair, A, Pendarvis, MP, \& Baldwin, B. (1997). The relationship between college zoology students' beliefs about evolutionary theory and religion. J Res Dev Educ, 30(2), 118-125.

Skoog, G, \& Bilica, K. (2002). The emphasis given to evolution in state science standards: A lever for change in evolution education? Sci Educ, 86(4), 445-462.

Solt, F, Habel, P, \& Grant, JT. (2011). Economic inequality, relative power, and religiosity. Soc Sci Q, 92(2), 447-465.

Stirrat, M, \& Cornwell, RE. (2013). Eminent scientists reject the supernatural: a survey of the Fellows of the Royal Society. Evolution, doi:10.1186/1936-6434-6-33.

Sturgis, P, \& Allum, N. (2004). Science in society: re-evaluating the deficit model of public attitudes. Public Underst Sci, 13(1), 55-74.

Sustersic, R. (2007). The impacts of religion and education on belief in evolution. In Andrew Young School of Policy Studies (pp. 1-25). Department of Economics. 
Swanson, CB. (2005). Evolution in state science education standards. In Editorial Projects in Education Research Center (Ed.). http://www.edweek.org/media/ epe_evolution1105.pdf. Accessed 1 May 2014.

Trani, R. (2004). I won't teach evolution; it's against my religion. And now for the rest of the story....Am Biol Teach, 66(6), 419-427.

Wagler, A, \& Wagler, R. (2013). Addressing the lack of measurement invariance for the measure of acceptance of the theory of evolution. Int I Sci Educ, 35(13), 2278-2298.

Wiles, JR, \& Alters, B. (2011). Effects of an educational experience incorporating an inventory of factors potentially influencing student acceptance of biological evolution. Int J Sci Educ, 33(18), 2559-2585.

Wilson, DS. (2005). Evolution for everyone: How to increase acceptance of, interest in, and knowledge about evolution. PLoS Biol, doi:10.1371/journal. pbio.0030364.

Winslow, MW, Staver, JR, \& Scharmann, LC. (2011). Evolution and personal religious belief: Christian university biology-related majors' search for reconciliation. J Res Sci Teach, 48(9), 1026-1049.

doi:10.1186/s12052-014-0024-1

Cite this article as: Rissler et al:: The relative importance of religion and education on university students' views of evolution in the Deep South and state science standards across the United States. Evolution:

Education and Outreach 2014 7:24

\section{Submit your manuscript to a SpringerOpen ${ }^{\circ}$ journal and benefit from:}

- Convenient online submission

- Rigorous peer review

- Immediate publication on acceptance

- Open access: articles freely available online

- High visibility within the field

- Retaining the copyright to your article

Submit your next manuscript at $\gg$ springeropen.com 